\title{
Politics Representation and Symbolic Violence through the Discourse of Seram as Nusa Ina
}

\author{
Flavius Floris Andries \\ Sekolah Tinggi Kristen Protestan Negeri \\ Email: qumran_2007@yahoo.com
}

\begin{abstract}
Political representation and symbolic violence through discourse Seram as Nusa Ina (Mother Island) are interesting phenomenon to be studied. This research was conducted with a qualitative method by in-depth interview and participation observation which aims to know how does this discourse view. The cultural study was applied in order to comprehend the manners of creating, producing, and disseminating the meanings from the perspective of non-Seram society and what their views on the discourse in understanding Moluccas universal identity. The process of data analysis by using the cultural studies approach generated the findings i.e the Nunusaku myth that legitimizes and strengthens Seram as Nusa Ina in society, and that there was a significant influence of myth and discourse in Moluccas identity formation universally in the form of folk songs or reliefs that always shade of Seram in represents the Moluccans. The discourse of Seram as Nusa Ina for the community of non-Seram, especially for Southeast people, is not substantial because they do not have emotional connection or relationship with the genealogy and cultural discourse. They have the other myth and the other own discourse about the myth itself such as Vernusang Island which was sinking in the formation of people's live in the Southeast. Therefore, the discourse of Seram as Nusa Ina which is forced to become a part of the discourse of Southeast People is a form of a false consciousness as well as form of political representation and symbolic violence.
\end{abstract}

Keywords: domination and cultural hegemony, political representation, Seram Nusa Ina, symbolic violence

\section{INTRODUCTION}

The discourse of Seram as Nusa Ina (Mother Island) has become an evolving discourse among the Moluccans from generations to generations. Through that narrative, Seram has been legitimized as the core of the Moluccans on the aspects of genealogy, culture, and economy. This can be observed through the Moluccas' symbols and songs, which tend to emphasize Seram as the core of life for Moluccans' societies.The discourse of Seram as Nusa Ina is legitimized through various myths, such as the myth of Nunusaku and Murkele (compare: Bartels, 1978; Pelupessy, 2012).
The discourse of Seram as Nusa Ina has been, in fact, dominating the narrative of Moluccans' identity with a claim that all Moluccans are originated from the island of Seram, while, in reality, not all Moluccans are originated from there.Itis revealed in the conclusion of Pattiasina's research that there are Moluccans, whoare originated from outside of Seram, such as Java and Makassar. Pattiasina provides an example of certain family name, Wattimury, which comes from China (Pattiasina, 2012). In addition, Ajawaila's research mentions the series of immigrations from other locations, including Kei, which come to 
occupy Seram Island (Ajawaila, 2000). Moreover, on cultural view, there are significant differences between the languages around the Central Moluccas and the languages around the Southeast Moluccas. There is also the fact, that social structures of the Southeast Moluccas' societies have their own characteristics and uniqueness. For instance, Kei has the caste system, while Seram doesn't recognize it. ${ }^{1}$ This explanation proves that the legitimacy of Seram, as the Mother Island or Nusa Ina, has to be critically reexamined and studied, in the context of not searching for justifications or errors, but rather to display other meanings and values, from the ones which already existed.

One of the considerations in conducting this study is to observe the reality of politics representation and symbolic violence practices, among Moluccas' plurality, with various ethnic groups, regions, languages, and traditions. Cultural centralization, "Seram-centered", is not only exercised as the symbol of solidarity bond among the Central Moluccans societies in the past, but also in the present, as it can be observed through the symbols and songs among the Moluccans. ${ }^{2}$ There are also various terminologies in governmental system, such as masohi, baileo, siwalima, and Pela-gandong. These terminologies are derived from a language in Seram and have been the symbols of Moluccas' identity, even though not all Moluccans have any attachment to this culture. This explanation shows that there are identity representations by the culture of Seram. The unawareness of this issue results in a potential cultural violence from one entity towards another, which there is a dominant narrative of certain culture that overpowering and oppressing other cultures.

On account to that, the purpose of this research is to examine the issue of politic representative and symbolic violence within the discourse of Seram as the main island, with an argumentative reason that Moluccans are not only originated from Seram. They also come from Southeast Mollucas and other places, with no connection to the history, genealogy, culture, and tradition of that narrative. On one side, the use of the discourse of Seram as Nusa Ina or the main island is an effort to encourage the solidarity bond or social integration of Moluccans under one collective culture. However, on the other side, there is a cultural domination and hegemony by the discourse of Seram as Nusa Ina towards other cultures which have no historical connections to the narrative. Therefore, the discourse of Seram as the Main Island or Nusa Ina is a production of certain culture which, if enforced, will be a media of representative politics and symbolic violence. In other word, it contains and preserves cultural violence from one society towards another.

The transformation from solidarity symbol into the media of domination and hegemony proves that the discourse of Seram as Nusa Ina, an aspect of culture, is not free from the authority's arrogance in the form of representative politics and symbolic violence. This research applies qualitative method with cultural studies approach to answer the questions of 1) what cause the production of the discourse of Seram as Nusa Ina, which indicates the occurrence politics representation and symbolic violence in the level of identity discourse in Moluccas? 2) How is the perspective of NonSeram socities towards this discourse?

The research is conducted in two locations. The first is in Seram (the village of Buria), to obtain data from informants regarding the historical foundation, in which the discourse of Seram as Nusa Ina is constructed. The second is in the city of Ambon to obtain data from Non-Seram informants regarding their origins, also their views and responses towards the discourse of Seram as Nusa Ina. The data analysis process is conducted using the cultural studies approach. This study is based on the critical approach with an effort to carry out intellectual reflection towards political, cultural, and even historical dynamics with the features that characterize them. These issues cannot be detached from the process of constructions; therefore the cultural studies are applied in order to comprehend the manners of creating, producing, and disseminating the meanings. The cultural studies are applied in this research within awareness that other regions in Moluccas have their own identity with different characteristics of culture, language, and tradition. There are even different narratives about their origins, but they are dominated by the discourse of Seram as Nusa Ina. Therefore, the cultural studies in this research will discuss the ideology within the discourse of Seram as Nusa Ina and how the narrative is created, 
produced, and distributed.

The data gathered are analyzed by means of interpretation process. This involves assigning meanings to the data through explanation and analysis within the assumption that the collected data are the result of construction. Therefore, the process of analysis also proceeds through the process of dismantling the existed meanings in the data as well as assigning new meanings. We will analyze, firstly the influence of myths in the production of the discourse of Seram as Nusa Ina. Based on the historical context of the development of discourse, there are two myths which influence the production of the discourse Seram as Nusa Ina. The first is Nunusaku Myth which was originated from Western of Seram. This myth is very popular in Mollucan societies. The second myth is Murkele myth which was initiated from Northern of Seram. On one hand, even though Murkele arrived lately and is not as popular as Nunusaku in the Mollucan society, both are strengthening the legitimating symbol of the discourse of Seram as Nusa Ina. On the other hand, the two myths are representing the internal conflict between Western Seram and Northern Seram people related to the origin of their life. In the Western of Seram, people believe that the Nunusaku is the place of early life. Meanwhile, people in the Northern of Seram consider Murkele as the place of early life. In fact, both are important to be discussed.

\section{FINDINGS AND DISCUSSIONS} The Influence of Myths in the Production of the Discourse of Seram as Nusa Ina

Myths have an important role in the process of identity construction within society. Even the discourses attached to the identity of a society are influenced by the myths. Therefore, the discourse of Seram as Nusa Ina is also influenced by the myths within the Seram's societies. The entitlement of Seram as Nusa Ina is related to the influence of mythology concept within Seram's societies that declares Seram as the first island to be created. In accordance with the glorification of the discourse of Seram as Nusa Ina, there are various versions of Seram's myths with the same objectives: to claim Seram as the center of Moluccans' life.

According to an informant who is the descendant of Seram's native from the village of Ririn (Western part of Seram):

The discourse of Seram as Nusa Ina is closely related to the story of Nunusaku. It is a story of the world in the cosmology of the people from Western part of Seram about a sacred mountain, Nunusaku, which also associated with a sacred tree. It is believed that life began at Nunusaku, with two big tribes, before eventually dispersed along the rivers bank, such as Tala, Eti and Sapalewa. ${ }^{3}$

The information about the myth of Nunusaku, in its association with the discourse of Seram as Nusa Ina, is also noticed through an interview with an informant (R), from the village of Kamal, who said that:

The discourse of Seram as Nusa Ina is intimately attached to the myth of Nunusaku. Based on the collected information, there is a form of glorification within the cosmology view of Seram's people towards Nunusaku, which is believed to be the Garden of Eden or the core of life. There is even a story that Noah's Ark was anchored around that region. According to this person, Seram is entitled as Nusa Ina because it has abundant natural resource which, in turn, becomes the core of life, especially in Moluccas. From this myth, there is a belief that all Moluccans are originated from Seram. ${ }^{4}$

The statement of Seram as the Garden of Eden is the informant's belief about his identity as the member of Seram's societies. This statement represents the developed discourse in Seram about people's belief on the exclusiveness of Seram and the holiness of Nunusaku, which is equal to the Garden of Eden. The Garden of Eden itself, in Christian's tradition, is believed to be the place where God created the first man.

The relationship between the discourse of Seram as Nusa Ina and the myth of Nunusaku is also implied by an informant with initial Y, who said that:

Nunusaku is the embryo of the term of Nusa Ina. There is an oral story that traditionally narrated by the Seram's elders 
about Ama (father) who was actually an outer space creature. Ama came and orbited around Seram. Eventually, Ama was attracted to the woman who solely inhabited the island. Because of that, Ama descended and visited the island to meet the woman. Ama finally decided to stay and live together with the woman. ${ }^{5}$

The above explanation clearly shows that there is a belief about the beginning of life. The woman, who was the first resident of Seram, married the man, who was an outer space creature, and started the entire life in Moluccas.

Language has been the production media for the discourse of Seram as Nusa Ina from generation to generation. The process of indoctrination and ideology-structuring in the discourse of Seram as Nusa Ina is conducted through verbal language. This process eventually displays language as the media of power and oppression, as it is explained by an informant:

If we see the Seram Island in the map, it appears to be hen-like, while small islands around it appear to be chick-like which are sheltered by their hen. Seram is a big island contains various sources of life, from where the life began before spreading everywhere. ${ }^{6}$

This statement shows that the application and explanation of symbols through language provides the legitimacy for the Seram's entitlement as the core of life for all regions in Moluccas. Here, language is functioned as the media to distinguish social status or to create social distinction, both semantically and pragmatically (Miles, 2010: 9-10). Therefore, unconsciously language can be the media of power, with the potential of creating oppression. In other word, language can be functioned to create symbolic power and symbolic violence (compare Harker 2009, Bordieu in Thomson 1991).

The myth of Nunusaku, through the substance of language within that story, has been the token of Seram's identity. The influence of this myth, which entitles Seram as the core of Moluccans' life, eventually promotes the discourse of Seram as Nusa Ina in the process of ideology-structuring, as the common ideology for all Moluccans. This issue revives the discourse of cultural and political representation and forming language as the favorite media in the process of culture production within collective Moluccas. However, in reality, not all Mollucans can accept that narrative as part of their culture, such as those originated from Southeast Moluccas and Southern Moluccas.The discussion about the response of Southeast Mollucans towards the Nusa Ina discourses is presented below:

\section{The Habitusof Non-Seram Societies towards the Discourse of Seram as Nusa Ina}

1. Nusa Ina in Moluccas Plurality Context.

The discourse of Seram as Nusa Ina is very meaningful in the perspective of Central Moluccans', while it has no significance for the Non-Seram societies. This can be seen through the result of an interview with a member of Southern Moluccas' societies, who said that:

The people of Kisar have different culture with Central Moluccans. There is even a significant difference between the story of Nusa Ina and the story originated in Kisar. This also influences the differences in languages, cultures, and the use of symbols between people in Seram and Kisar. The Central Moluccans have customary house which is called Baileo, while the customary house in Kisar is called Romlapa. There is also a tradition of nose kissing, Nahwook, which is similar with the one in Kupang. This tradition of nose kissing is a sign of identity for people in Kisar, which is Seram's people do not possess. Based on that, in my opinion, it is an exaggeration if the discourse of Seram as Nusa Ina is linked to Kisar. $^{7}$

Non-Seram people, such as those from Kisar, consider themselves to have no cultural attachment to Seram. Therefore, the discourse of Seram as Nusa Ina has no cultural and genealogic attachments to the Southeast Moluccans.

Consequently, the affirmation in the discourse of Seram as Nusa Ina in various symbols and songs indicating that all Moluccans are originated from Seramis irrelevant to the existed social and cultural reality. The following statement approves this fact:

Although it cannot be denied that there are familial relationships between the people 
of Southeast and Seram, especially Geser, the people of Kisar are not originated from Seram. They believe that their ancestors came from Luang. ${ }^{8}$

The statement above proves that Non-Seram people have different tales about their history and origin, particularly those who inhabit the island of Kisar. The people of Tepa also do not recognize Seram as the place of their origin, as it is constructed in the myth of Nunusaku or Murkele. They have their own myth in constructing their identity. An informant with initial J explains it, as follows:

Speaking about the identity and origin of the Southeast Moluccans, we also have a mythical story about the forming of the islands. In the past, all of the Southeast Moluccans lived in Vernusang Island. Then, the sinking of Vernusang Island resulted in the emergence of the islands of Yamdena and Selaru, and caused a dispersion. ${ }^{9}$

There are two points to be considered; 1) the Southeast Moluccans also have myths about the forming of islands and the origin of societies that spread around that region, 2) the cultural diversity results in the variety of stories about the origin, which proves that there is no dominant culture among the Moluccans.

Because of that, the discourse of Seram as Nusa Ina, that influences all dimensions (social, bureaucratic, and political) of Mollucans' life, is considered to be incorrect. The impact is that the effort of legalization towards the discourse of Seram is more dominant than the other region. An informant with initial $\mathrm{O}$, specifically assigns the term "forgotten islands" to identify certain regions in Southeast part of Moluccas. This term is given because these islands have relatively tiny size compared to the enormous size of Seram. ${ }^{10}$

Based on the information above there is a multicultural problem related to the misrecognition of the other culture existence, which are regions outside of Seram. This appears as representing the absence of cultural recognition of other which further neglects appreciation of their identity and civilization.

Taylor (1994: 25) implies that identities are mostly formed through recognition. Without recognition, the absence of appreciation and awareness towards others' identities will occur. In this context, misrecognition not only shows the lack of respect, but also generates a terrible trauma, self-loathing, and social status incapacitation. Taylor's perception is based on the practice of discrimination the Negroes. For several decades, the Whites entitled themselves as elites and undermined the Negroes.

Based on the preserved and trusted mythologies, the discourse of Seram as Nusa Ina, in its consideration as the core of all life in Moluccas, is a denial to the fact of the Moluccas' diversity. Principally, all individuals, tribes, ethnic groups, or even races, have their own history and civilization in the relation to the construction of their identities. Therefore, the absence of cultural recognition towards others, within this narrative, is absorbed as the absence of appreciation and awareness of other identities. This denial causes the practice of intolerance, misrecognition, and unjust treatment, towards the discourse of other regions origins.

Cultural recognition is essential in the implementation of multiculturalism concept, in which, all individuals and groups are equally and respectfully treated. Taylor (1994: 30) implies that the importance of cultural recognition is caused by the social fact in which our identities are negotiated through cultural dialogue with others. On account to that, cultural recognition is very important to 1 ) avoid frictions in relationship among the existed cultures; 2) provide freedom for each culture to display its existence; 3 ) maintain the culture existence amidst the reality of a society or a nation. Hence, all individuals and groups can apply their own cultural identity and discover the values within it.

The cultural recognition of Seram as Nusa Ina, which based on the myth of Nunusaku, introduces domination and hegemony of Seram's culture towards Non-Seram's cultures. For instance, the use of names and symbols in Seram's language as the representation of Moluccas' culture. Central Moluccas' culture has been the dominant culture in Moluccas, while other cultures have merely been complements. Therefore, the values of cultural recognition have not emerged in the Moluccas' multiculturalism. 
On the other hand, the narrative of the forgotten islands is a form of expression to indicate the reality that Non-Seram's culture is forgotten in the context of collective Moluccas. The discourse of Vernusang is an effort to oppose the discourse of Seram as Nusa Ina in its role of constructing the perspective about the origin and identity of all Moluccans. The revelation of the myth of Vernusang, in the effort of constructing the identity of Southeast Moluccans, is a form of refusal towards the dominant narrative. Spivak labels this attitude as counter knowledge and counter hegemony (Spivak, 1998).

\section{The Discourse of Seram as Nusa Ina: a Form of} Identity Discrimination.

Regarding to the aspect of identity, the discourse of Seram as Nusa Ina displays domination and hegemony of Seram's identity towards other identities. It resulted in the identity discrimination, which is explained by an informant with initial $\mathrm{O}$ :

In my opinion as the member of NonSeram's societies, the discourse of Seram as Nusa Ina is a form of domination towards Non-Seram's cultures, especially the cultures of Southeast Moluccans. We, the Southeast Moluccans, do not recognize that discourse and do not consider ourselves to be the part of Seram's socities, both historically and culturally. For instance, there are differences between traditional dances from Seram and Southeast. The traditional dances in Southeast are even more similar to the ones in Papua and East Nusa Tenggara. Another example of the domination is the excessive use of Central Moluccas'terms, such as Masariku, Masohi, Siwalima, Kabaresi, Salawaku, etc. The Southeast Moluccans have neither attachment nor even mere understanding of these terms. However, we are enforced to share and use these terms. ${ }^{12}$

The statement above explains that there are politics representation through the discourse of Seram as Nusa Ina, including the use of symbols and terms entirely within Seram's nuance. This discourse has a very powerful influence within both social and bureaucratic system in Moluccas.
Eventually, it is accepted by all Moluccans. Fanon (2005) labels the domination of Seram cultures as the form of symbolic violence, because it entitles Seram as the subject and the other regions/ identities as the object of domination.

Non-Seram people, especially Southeast Moluccans, have perceptive insight towards this reality. They realize that the discourse of Seram as Nusa Ina entitles Seram as the mother and other regions as its children. The entitlement of Seram as the core of Moluccas' life results in the centralization of power within certain regions and ethnic groups. One of the informants with initial O confirms it:

The influence of the discourse of Seram as Nusa Ina is a very important issue for bureaucratic system in Moluccas province. Therefore, the use of Central Moluccas' symbols and terms are dominant. Central Moluccas' terms like Pela-Gandong, Masohi, Patasiwa-patalima, and Siwalima have been enforced to be the common ideology, even though the Southeast Moluccans have other terms for those, such as Kinabela and Kalwedo in their social system. The more prominent use of Central Moluccas terms within the bureaucratic system appears in the Moluccas' Marching Tune, in which its lyric contains the nuance of Central Moluccas (Seram) such as the terms Masohi, Siwalima, etc. In my opinion, it is very unfortunate that the discourse of Seram as Nusa Ina contributes in influencing the politics of power. The Southeast Moluccans can sing this song but hardly accept it as the common ideology. ${ }^{13}$

The statement above explains that Non-Seram people especially the Southeast Moluccans realize the existence of politics representation, which prioritize certain culture and ignore other cultures. Even though, Non-Seram people do not accept Seram's culture as their ideology, they do not complain because they have no authority to do so.

Spivak (1998) recognizes these people as the marginal or subaltern group. They are the object of the power. Their identities are constructed by regime that supports the dominant narrative (grand narrative) and constantly oppresses the minor 
narratives. The regime uses the dominant narrative to oppress the subaltern group; hence it becomes not only the element of politics representation but also symbolic violence.

The Central Moluccas symbols within terms, Moluccas Marching tune, and reliefs have become the token of identity of the collective Moluccas. This is caused by the reigning regime, which constantly operates to enforce the discourse and the system of symbols from certain culture to become a common ideology (Bourdieu in Jenkins, 1992: 66). Despite their disagreement, the discourse of Seram as Nusa Ina, with its entire system of symbols, is consciously accepted by the Southeast Moluccans.

The acceptance of Seram's culture as part of their identity is chosen because they are oppressed by those who want to legalize the culture of Seram as the common culture. Herewith, the politics representation can be obviously observed through the discourse of Seram as Nusa Ina. Its entire system of symbols, both languages and signs, is used as the identity expression.

The discourse of Seram as Nusa Ina finally becomes the sign of symbolic violence on other cultures. This is a threat towards Moluccas as an integrated union, in geographical, social, and political aspects. For Non-Seram people, particularly in Southeast Moluccas, the discourse of Seram as Nusa Ina is a discourse of violence which eradicates and eliminates others' identities, including the Southeast Moluccans' identity. According to Bourdieu, the dominant identity, the Central Moluccas' or Seram's identity in the context of Moluccas, principally serves the interest of certain group while showing it as common interest (Bourdieu, 1991: 167).

Moreover, the discourse of Seram as Nusa Ina is an effort of identity homogenizing, using Seram's symbols as the sign of Moluccas' identity. With the assumption of Seram as the core of Moluccans' life, the coercion of symbolic system is occurred (compare Bourdieu in Jenkins, 1992: 66). Unconsciously, there is coercion in many aspects such as in system of symbols in Moluccas. For example, the use of local clothes as office uniforms, the christening of sport buildings and other facilities using Seram's terms, etc. Therefore, the identity homogenizing, based on the perspective that Seram is the core of life in Moluccas, marginalizes other identities. It is parallel to Bourdieu's thought which implies that language has potential to create oppression (Harker, 2009). The homogenizing of identity, with Seram as its core, plays an important role in the integration process of the Moluccas as a unity. However, it is also turned out to be the process of distribution of False Consciousness by the dominant society against other societies. As the impact, even though the enforcement of Seram as the core of life will be a problem, Non-Seram people have to submit to this process because they have no other options.

People or societies outside Seram also have their own cultures with traditions, languages, even myth and legend, in relation to both their origins and identities. However, those discourses are lack of appropriate attention in the context of social integration in Moluccas' societies. This happens because the discourse of Seram as Nusa Ina has been the only discourse and ideology for a long time and is used as reference in the process of social integration among Moluccas' societies. The phenomenon is supported by Bourdieu's idea (Bourdieu, 1991: 166). He implies that symbols have power in the construction of reality. It can also create the consensus in intellectual or knowledge diversity which is conducted by the power holders.

In the reality of power structure, the discourse of Seram as Nusa Inais unacceptable by NonSeram, but still politically accepted as common narrative because of the power's constrain. However, it does not spontaneously receive recognition as common narrative, both culturally and socially. ${ }^{14}$ The cultural rejection towards this narrative appears through the myth of Vernusang and the discourse of forgotten island. Likewise, the refusal of the Central Moluccas' symbols can be seen through the terms Romlapa as the name of customary house and the tradition of nose kissing as the symbol of identity.

These identities have been forgotten, reduced, or even dissolved within the dominant culture, which is heavily influenced by Central Moluccas' culture. In the context of an integrated Moluccas, Seram's culture is the icon. Particular identities of other regions are declined. Hence, those identities become the cultural discourse of subaltern or inferior groups. Meanwhile, Seram's culture appears in the surface and becomes the dominant discourse. 
Antonio Gramsci (Ave Leffan, 2012) applies the term subaltern in order to show the inferior groups within a society, which have been victimized by the hegemony of the ruling class. Farmers, laborers, and other minor groups do not have access to authority. He mentions that the histories of the subaltern groups are as complex as the dominant history. However, only the dominant history is recognized because the subaltern groups do not have appropriate access to their own history in order to represent themselves within cultural and social institutions. Similarly, Spivak (1998) also exposes the issue of subaltern by displaying the domination, which in turn creates social, economy, and political inequalities between the elites and the ordinary people.

Guha (1988: 35-44), an Indian historian who studies the subaltern groups, also adopted Gramsci's idea to encourage himself in rewriting Indian history with the title: On Some Aspect of Historiography of Colonial India. He mentions that the dominant history about the nationalism of India does not include the subaltern groups: the working class and the middle class. Based on the proposition from Gramsci and Guha, the introduction of the term forgotten island can be assumed as the term to express the existence of subaltern group within a society.

The subaltern groups are those who in one side still maintaining their own culture, while on the other side have to submit to other's narrative and recognize it as their own. In the process of forming the narrative of Moluccas, there is no consideration to include other narratives from the culture of Non-Seram societies. Therefore, the subaltern class in the context of Moluccas is Non-Seram and non-Central Moluccas societies, such as the Southeast Moluccas. In other word, this group's identity is not only forgotten but also culturally oppressed, because of the status quo of the dominant culture. It can be identified as False Consciousness, in which Non-Seram have to reluctantly recognize every forms of Seram's culture as their own, while emotionally alienated from that culture.

3. The Discourse of Seram as Nusa Ina: a Form of

Politics Representation and Symbolic Violence

Based on a review of the cosmology of the people of Seram, the discourse of Seram as Nusa
Ina is a discourse that nurtured verbally from generation to generation and became ideology for its own people. Even though in reality, there are various myths to legitimize it, the discourse of Seram as Nusa Ina, for its people, is a certain and valid discourse. Therefore, it is maintained and believed as a virtue in every context. Meanwhile, it is not applied by Non-Seram people.

Non-Seram people also have their own stories in regard to their origins, which are different from Nunusaku story. This can be proved by the stories in Southeast Moluccas which contains significant differences to the Nunusaku or Murkele stories, in which enormous influence in provide legitimating for the discourse of Seram as Nusa Ina resides. The myth of Vernusang is a myth which describes the history of the forming of life in Southeast Moluccas. The myth of Vernusang appears as an important cosmology for the Southeast Moluccans as well as the myth of Nunusaku or Murkele for Seram's people. Similar to Seram as the origin and source of life in Moluccas, the sinking of Vernusang Island is assumed to be the beginning of life in Southeast Moluccas. Therefore, there is an opposing discourse which also functions as the confirmation that the life in Southeast Moluccas has no attachment whatsoever to the discourse of Seram as Nusa Ina.

The discourse of Seram as Nusa Ina, as a form of politics representation, is not isolated in Seram and its surrounding, but has been widely spread. It is enforced to be a common discourse regardless other regions' discourses. It results in the representative politics, with constructed values from the dominant power. The representation of cultural, political, and social reality is constructed by a dominant authority which oppresses others.

The discourse of Seram as Nusa Ina, which considered as the core of Moluccas' life, is a tool to form ideology within society. It is strengthened not only by myths of Nunusaku or Murkele but also through songs and the use of its symbols in bureaucratic system. Synchronized with Frantz Fenon's thought, the discourse is a form of symbolic oppression, because there is a dominant subject who always represents the objects. It is the coercion of subject's beliefs towards the objects' and represents the generalization of the objects' beliefs (Fanon, 2005). The symbolic annexation 
directly indicates the symbolic violence towards the cultures outside Seram. Those cultures, as implied by Spivak, are the culture of marginalized subaltern groups. Locally, they still express their local identities within their local boundaries. However, outside the boundaries, they are enforced to use other's identity. This is the False Consciousness, where there is recognition and acceptance for something different to be the part of their identity.

Cultural alienation is a reality for the community outside Seram, such as the Southeast Moluccas that happens because of the discourse of Seram as Nusa Ina. As it is mentioned before, for the people of Kisar, the customary house is called Romlapa. They do not recognize the terms Masohi and Baileo, but in the context of common identity as a part of Moluccans, these terms appear to be the representation of all Moluccans identity. The local identities outside Seram are dissolved into the identity of Moluccas with the initial of Seram. Their own identities are declined and become voiceless. Arbitrary and hybrid phenomenon express the differences between dominant and subdominant groups in their ability to maintain the cultural representation as a symbolic violence.

Because of that, the discourse of Gramsci's subaltern, which is used by Guha in observing the phenomenon of life in India, through the shifting of discourse dealing with subaltern as a white-black, inside-outside, colonial-anti colonial, employeeemployer dichotomy, and being the elites and the subaltern in the context of Moluccas is obvious in the discourse of Seram as Nusa Ina. Therefore, in discussing about cultural discrimination and hegemony, there is a necessity to focus on "stake holders," because the cultural annexation occurs not only from the outsiders' cultures but also from the insiders'. Colonial practice has never ended. It will always appear in various ways in order to maintain status quo.

The discourse of Seram as Nusa Ina, which is supported by the myths of Nunusaku and Murkele, is the representation of the elites' culture. Meanwhile, the myth of Vernusang, almost unnoticed, can be described as the subaltern's culture. The myth of Nunusaku and Murkele legitimizes the discourse of Seram as Nusa Ina to be familiar with and attached to the elites. In the context of a collective Moluccas, these elites consistently use the discourse of Seram as Nusa Ina for various interests and do not allow the use of others' discourses.

The subaltern class represents the groups that are socially and culturally annexed, whereas they actually have the same social, cultural, and even economical provision, to the ones attached to the dominant class. However, the delay in the production of their discourses causes the subaltern to join in and accept the dominant culture which has been used for an extensive period of time as a common identity for all Moluccans. Other discourses such as Vernusang cannot have the same echo as Nunusaku and Murkele. The Southeast Moluccas' natural resources cannot be compared to Seram. Likewise, the philosophical values of NonSeram cultures cannot be weighed against Seram's values, even though they have similar ethicalmoral elements. Everything is Seram-centered.

The discourse of Seram as Nusa Ina has formed a tendency of cultural hegemony of Central Moluccas culture over other cultures. This tendency influences not only the bureaucrats and politicians, but also local artists who participate in glorifying Seram through the lyrics within the songs. Beautiful notations and comforting lyrics impressing peace and unity are composed in the spirit to serve the interests of domination of certain culture, or even certain political party. This situation provides more energy for the preservation of Seram-centered culture in Moluccas, which in turn initiates the Neo-colonialism practice.

As it is discovered in this research, the discourse of Seram as Nusa Ina, in its relation to collective Moluccas, shows the occurrence of representative politics and symbolic violence towards the discourses of other cultures, such as the myth of Vernusang. The incapability of the myth of Vernusang to challenge the myth of Nunusaku or Murkele also contributes in legitimating the discourse of Seram as Nusa Ina. The influence of this discourse affects all of the process of symbolic naming. Language and culture of Central Moluccas is used in representing collective Moluccas, hence the symbolic violence in the form of cultural hegemony under the domination of Seram or Central Moluccas' culture.

Moluccas is not only consisted of Seram. 
Every culture develops in synchronization with the myth that legitimizes it. Because of that, the cultures within Moluccas are heterogenic. There are various languages, traditions, customs, and even arts. For instance, Seram and Southeast Moluccas have great difference in language, tradition, custom, and art. Therefore, it is very difficult to identify Seram as the core or origin of the Southeast Moluccas' culture, as it is implied by the discourse of Seram as Nusa Ina.

This explanation shows the fact that there is no supreme culture in a society, hence entitling Seram as Nusa Ina in the context of collective Moluccas has to be reconsidered. It does not mean to replace or deconstruct the narrative with others. The cultural studies' paradigm is not intended to exterminate certain culture and replace it with another, but more to raise awareness within a society about the fact of the variety of cultures. In relation to various identities, cultural studies' paradigm seeks to promote the fact that there is no dominant culture in any existing society.

Besides showing identity awareness, the emergence of the myth of Vernusang is the form of identity struggles against the discourse of Seram as Nusa Ina by Southeast Moluccans. Due to this, it is important to realize that Moluccas culture is not isolated only on Seram and to reconsider the existence of each region with their cultures, customs, and myths about their origins. The myth of Vernusang, as the source of life in Southeast Moluccas, offers a collective consciousness about the existence of culture in each region without domination or hegemony by any other cultures.

\section{CONCLUSION}

Based on the explanation and analysis of the issue of politics representation and Southeast Moluccas within the discourse of Seram as Nusa Ina, there are several conclusions to be formulated:

The development of the discourse of Seram as Nusa Ina is aligned to the myth of Nunusaku, which provides legitimacy. Myth becomes the production media of discourse and signifying the meanings, while the distribution of meanings is performed through the use of language, both in song's lyrics and symbols.

Language is still the main feature in discussing discourse, especially that which have relation to socio-cultural. This research discovers that the discourse of Seram as Nusa Ina, strengthened by supporting myths, has become an absolute reality for all Moluccans. According to Van Dijk, discourse is not only a practice of language, but also a media used by certain groups to socially disperse and expose their own faith, values and ideology. Therefore, it can be pronounced that discourse holds a certain social cognition. Cognitive approach is based on the assumption that a text does not have meaning on its own, but it is given through the use of language, more exactly the mental consciousness of the language users.

The discourse of Seram as Nusa Ina can be structured as a practice of naturalization and depoliticized in the domination of meanings so that the ideology is featured as appropriateness, without any political interests. On account to that, the ideology in this narrative is not a deterministic concept or False Consciousness, but dispersed as a practice of structural representation through social attitudes, perspectives, and relations, which entitled Central Moluccans with higher status compare to Southeast Moluccans

The mobilization of meanings within the discourse of Seram as Nusa Ina cannot be unraveled from the discourses that have relationship with particular issue in the period of colonial and postcolonial. Based on this concept, Foucault thought can be used as a connector between narrative text in the context of social historical including colonial and postcolonial cultures and the application of economic and political system in a society. Foucault establishes those meanings as the forming of discourse subject of individual and the knowledge of discursive practice which intertwined with discursive formation within the society.

Powerful ideology is no longer viewed as coercion because the society obtains an explanatory discourse and knowledge with scientific consideration about certain issues; hence they will establish it as fact and necessity. Then, individuals within society are created as a subject in relation to the power through the discourse and knowledge which proposed rationality.

Based on Foucault thought, the discourse of Seram as Nusa Ina can be defined as the structure of narrative world that is produced by the regimes 
at that time. Within this structure, a discursive practice exists, in which discourses and knowledge about historical and particular within the society emerged as the authoritative mechanism.

The language that dominates the discourse is a media to preserve the practice of representative politics and symbolic violence, which occurs through the discourse of Seram as Nusa Ina. Bourdieu's (1991) idea about language as an entity that becomes a virtual social practice can be seen through this narrative. The use of language as symbolic authority can be seen practically through the discourse of Seram as Nusa Ina, which is approved by Moluccans without any awareness of the restriction within this narrative.

The study of the discourse of Seram as Nusa Ina through cultural studies approach dismantles the power of myth in creating meanings and raises a new consciousness about this discourse as the media of politics representation, which is legitimated by the myth of Nunusaku or Murkele. Even though there are opposing myths within Seram itself, in the context of the discourse of Seram as Nusa Ina, these myths are the media to produce supremacy and legitimate discourses.

Because of that, the discourse of Seram as Nusa Ina is ranked as the highest discourse among other discourses in Moluccas, including those from Southeast Moluccas. The supremacy of the discourse of Seram as Nusa Ina has become the media to represents collective Moluccas, both culturally and politically, and caused the Southeast Moluccans to entitle themselves as the forgotten island or marginalized groups.

\section{Notes}

1. Interview Result with informant initial $\mathrm{O}$, who is the Southeast people from Babar island, September, 2013.

2. Interview Result with informant initial $\mathrm{J}$ from Central Mollucas, who is young Mollucan historian and also lecturer at Pattimura University, March, 2014.

3. Interview Result with informant initial $O$, who is academic staff at Pattimura University, August 2, 2014.

4. Wacana Seram sebagai Nusa Ina sangat berkaitan erat dengan cerita Nunusaku yakni sebuah cerita tentang suatu dunia yang dalam kosmologi orang Seram bagian barat tempatnya berkedudukan di gunung keramat yakni Nunusaku dan identik dengan sebatang pohon yang keramat pula.Kehidupan awal di Nunusaku terdiri dari dua suku besar, pada akhirnya terpencar-pencar menjelajah mengikuti aliran Air yakni Tala, Eti dan Sapalewa.

5. Interview Result with informant initial R, Who is Seramness,August25, 2014. Wacana Seram sebagai nusa ina memiliki hubungan erat dengan mitos Nunusaku. Berdasarkan infomasi yang ditemukan terdapat pengagungan terhadap dunia dalam pandangan kosmologi orang Seram terhadap Nunusaku yang diyakini sebagai taman Eden atau pusat kehidupan. Bahkan ada cerita juga yang turut berkembang bahwa bahterah Nuh terkandas di daerah itu. Menurut beliau Seram di sebut sebagai Nusa ina karena berlimpah dengan segala sumber daya alam yang sekaligus merupakan sumber kehidupan khususnya di Maluku. Dari mitologi tersebut ada semacam keyakinan bahwa semua orang Maluku berasal dari Seram.

6. Interview Result with informant initial Y from Seram Island, who is a lecturer at The Christian Protestan State Collage, October, 2014.

Nunusaku adalah cikal bakal orang berbicara mengenai "Nusa Ina".Ada sebuah oral tradisi dari orang tua-tua bahwa sebetulnya ama (bapak) adalah mahkluk luar angkasa datang dan mengelilingi pulau Seram dan tertarik dengan adanya seorang perempuan sebagai satu-satunya penghuni pulau itu.Pulau tersebut merupakan pulau kosong. Karena niat ingin mengenal perempuan itu, maka sang ama akhirnya mengunjugi pulau tersebut dan berkenalan dengan perempuan tersebut. Karena sang ama jatuh hati dengan perempuan tersebut akhirnya memutuskan untuk tinggal bersama.

7. Interview Result with Informant initial Y from Seram Island, who is a lecturer at The Christian Protestan Collage, October 2, 2014.

Jika kita melihat pulau Seram maka terkesan ia seperti induk ayam yang dibawahnya terdapat pulau-pulau kecil seperti anak ayam dan hidup dari induknya. Seram itu pulau besar dan dari pulau itu kehidupan dimulai dan tersebar 
kemana-mana.Pulau seram mengandung beragam sumber kehidupan.

8. Interview Result with informant initial $\mathrm{T}$, who is Southeast people, August19, 2014.

Orang Kisar memiliki tradisi yang berbeda dengan orang di Maluku Tengah, bahkan ada perbedaan signifikan antara cerita nusa ina dengan cerita asal usul di Kisar. Hal ini juga yang berpengaruh terhadap bahasa, dan budaya serta penggunaan simbol yang berbeda antara orang di Kisar dan di Seram.Orang Maluku Tengah memiliki rumah adat yang disebut Baileo, demikian juga di Kisar ada rumah Adat tapi orang di Kisar menyebutnya Romlapa. Demikian juga orang Kisar memiliki tradisi cium hidung yang disebut "nahwook" yang sama dengan di Kupang. Cium merupakan tanda identitas bagi orang Kisar yang sama sekali tradisi ini tidak nampak di Seram. Oleh sebab itu bagi saya wacana Seram sebagai nusa ina jika dihubungkan dengan orangorang di Kisar maka hal itu merupakan suatu hal yang berlebihan.

9. Interview Result with informant initial $\mathrm{P}$, who is Kisar people, August20, 2014.

Orang Kisar bukan berasal dari Seram, walaupun tidakdipungkiribahwa ada hubungan kekeluargaan antara orang Tenggara dengan Seram Khususnya Geser, namun bagi orang Kisar mereka meyakini bahwa leluhur mereka berasal dari Luang.

10.Interview Result by informant initial $\mathrm{J}$, who is Tepa people, September19, 2014.

Ketika berbicara mengenai identitas dan asal usul orang Tenggara, maka kami juga memiliki cerita mitos yakni tenggelam pulau Vernusan yang mengakibatkan muncul Yamdena, Selaru dan terjadi penyebaran. Orang Tenggara juga memiliki mitos tersendiri terkait pembentukan pulau-pulau di bagian Tenggara. Semua orang Tenggara dulu terkumpul di pulau Vernusan.

11. Interview Result with informant initial $\mathrm{O}$ from Babar Island, August 2014.

12. Interview Result with informant initial $\mathrm{O}$ from Babar island, August 14, 2014.

Wacana Seram sebagai Nusa ina secara jujur bagi saya sebagai bagian dari masyarakat non Seram, merupakan suatu bentuk dominasi terhadap kebudayaan non Seram secara khusus budaya orang tenggara. Kami sebagai orang Tenggara tidak mengakui wacana tersebut, dan tidak merasa diri sebagai bagian dari masyarakat Seram baik secara historis maupun budaya.Hal ini disebabkan karena dari sisi budaya ternayta tarian Maluku Tenggara berbeda dengan tarian di Seram bahkan tarian di Tenggara mirip dengan tarian di papua dan di Nusa Tenggara Timur. Demikian juga dari segi Kapata: dominasi Maluku Tengah begitu kuat yang bagi saya hal tersebut merupakan pengaruh dari ideology tentang seram sebagai Nusa Ina. Seperti contoh, masariku, masohi, Siwalima, kabaresi, Salawaku dan lain-lain, bagi orang Tenggara secara kultural kami tidak memiliki hubungan bahkan tidak mengerti tentang hal tersebut. Namun dipaksakan untuk menjadi ideology bersama.

13. Interview Result with informant initial $\mathrm{J}$, from Babar island, September 2, 2014.

Pengaruh wacana Nusa Ina juga menjadi hal terpenting dalam sistem birokrasi pemerintahan di provinsi Maluku sehingga penggunaan simbol Maluku Tengah dan kapat-kapatnya menjadi dominan. Kapatakapata Maluku tengah seperti pela-gandong, patasiwa-patalima, masohi, Siwalima dipaksakan untuk diterima menjadi ideology bersama walaupun bagi orang Tenggara lebih mengenal Kinabela dan Kalwedo dalam sistem sosial kemasyarakatan mereka. Hal lain yang leboh menonjol dalam penggunaan simbol Maluku Tengah dalam birokrasi pemerintahan melalui lagu mars Maluku yang syairnya bernuansa Maluku Tengah (Seram) dengan sebutan siwalima, masohi. Bagi saya di sini terlihat jelas dampak dari wacana Nusa ina turut memengaruhi politik kekuasaan dan hal ini yang disayangkan. Bagi orang tenggara karena itu lagu boleh saja dinyanyikan tetapi untuk menjadi ideology bersama agak susah 14. Interview Result with informant initial M, from Saumlaki, August12, 2014.

15.Interview result with informant initial O, From Tepa, Agustus, 15, 2014.

Seram Sebagai nusa ina secara politik kami terima karena kami tidak memiliki kekuatan untuk melawannya, namun secara sosial dan kultural narasi itu terlalu asing bagi kami. 


\section{REFERENCES}

Ajawaila. Jacob. N. (2000). Orang Ambon dan Perubahan Kebudayaan, Jurnal Antropologi Indonesia, vol. 61, pp 16-25.

Althusser, Louis (1971). Lenin and Philosophy. New York: Monthly Review Press.

Barker, Chris (2000). Cultural Studies, Theory and Practice. London: Sage Publication.

Bourideu, Pierre (1977). Outline of a Theory of Practice. Canbridge: Cambridge University Press.

(2005). Cultural Studies: Teori dan Praktik (Terj). Yogyakarta: Bentang.

Bartels, Dieter. (1978). Guarding The Invisible Mountain: Intervillage Alliances, Religious Syncretism and Ethnic Identity Among Ambonese Christians and Moslems In The Molucas.Michigan: Cornell University.

Fanon, Frantz (2005). Black Skin, White Masks. New York: Grove Press.

(1981). The Order and Power, in Paul Rainbow (ed.) Foucault, Reader. New York: Panthean Books.

Foucault, Michel (1998). The Will to Knowledge, the History of Sexualities Volume 1 (English trans. Robert Hurley), London: Penguing.

(2002). Arkeologi Pengetahuan. (trans.) oleh H. M Mochtar Zoerni), Yogyakarta: Qalam.

(1980). Power and Knowledge. Brighton: Harvester.

Hall, Stuart (2007). The Problem of Ideology, Marxism Without Guarantees. in David Morley and Kuan Hsing Chen (eds) Stuart Hall, Critical Dialogue in Cultural Studies.London: Routledge.

Hall, Stuart (1997). The work of Representation. in Stuart Hall (ed) Representation, Cultural Representation and Signifying Practices. London: sage publication.

Harker, Richard (2009). (HabitusxModal) + Rana $=$ Praktik: Pengantar Paling Konprehensif Kepada Pemikiran Pierre Bourdieu. Yogyakarta: Jalasutra.

Heck, Marina Camargo (1980). The Ideological Dimension of Media message. In Stuart Hall, dkk (eds) Culture, Media and Language: Selected Working Papers in Cultural Studies, 1972-1979. London: Routledge.
Jenkins, Richard (1992). Pierre Bourdieu, London: Routledge.

Lefaan, Ave (2012). Etnosentrisme Dan Politik Representasi di Era Otonomi Khusus Papua, Disertasi, Kajian Budaya Dan Media, Yogyakarta, Sekolah Pascasarjana, UGM.

Marsetio (2011). Konstruksi Marginalitas Daerah Perbatasan: Studi Kasus Kepulauan Natuna. Disertasi, Kajian Budaya dan Media, Yogyakarta: Sekolah Pascasarjana, UGM.

McHoul, Alec\&Wendy, Grace (1993). A Foucault Primer: Discourse, Power and the Subject. London: Routledge.

Myles, John, F. (2010). Bourdieu, Language and Media. New York, Palgrave, Macmilian.

Patiasina, Johan (2011). Taong Flaming: Perubahan Formasi Etnis, Sosial dan Keagamaan di Saparua. (Tesis) Yogyakarta: Universitas Gadjah Mada,

Pelupessy, Pieter, Jacob (2012). Esuriun Orang Bati. (Disertasi), Salatiga: Universitas Kristen Satya Wacana.

Ranajit, Guha (1988). On Some Aspects of the Historiography of Colonial India, Selected Articles from Subaltern Studies, Oxford University Press, p. 35-44.

Ritzer, George and Goodman (2010). Teori Sosiologi: dari teori Sosiologi Klasik Sampai Perkembangan Mutakir Seori sosial Postmodern. Yogyakarta: Kreasi Wacana.

Spivak, Gayatri (1988). Can Sub Altern Speak? Marxism and the Interpretation ofCulture, Columbia: Columbia University Press.

Thompson, John, B. (1991). Introduction in Pierre Bourdieu Languange and Symbolic Power. Cambridge: Polity Press.

Thwates, Tony, dkk. (2002). Introducing Cultural and Media Studies: A Semiotic Approach. London: Macmillian, Palgrave.

Taylor Charles (1994). Multiculturalism: Examining the Politics of Recognition. Princeton, New Jersey: Princenton University Press.

Vand, Dijk Teun, A. (1995). Power and The News Media, in political Communication and Action, New York: Hampton Press.

Wickman, Gary (2008). The Social Must Be Limited: Some problems with Foucault's Approach to Modern Positive Power, Journal Sociology, Vol. 44, No 1. 
Flavius Floris Andries - Politics Representation and Symbolic Violence through the Discourse of Seram

Widder, Nathan (2005). Foucault and Power Revisited: in European Journal of Hall, Stuart, 1986 , The Problem of Ideology, Marxism Without
Guarantees. Journal Cultural Studies Art and Humanities, London: Routledge, Vol. 10, no. 2. 